\title{
AUTHENTICITEIT EN MATERIAAL
}

\section{EEN VERKENNING VAN HET BEGRIP AAN DE HAND VAN (LAAT)ANTIEKE EN MIDDELEEUWSE VOORBEELDEN}

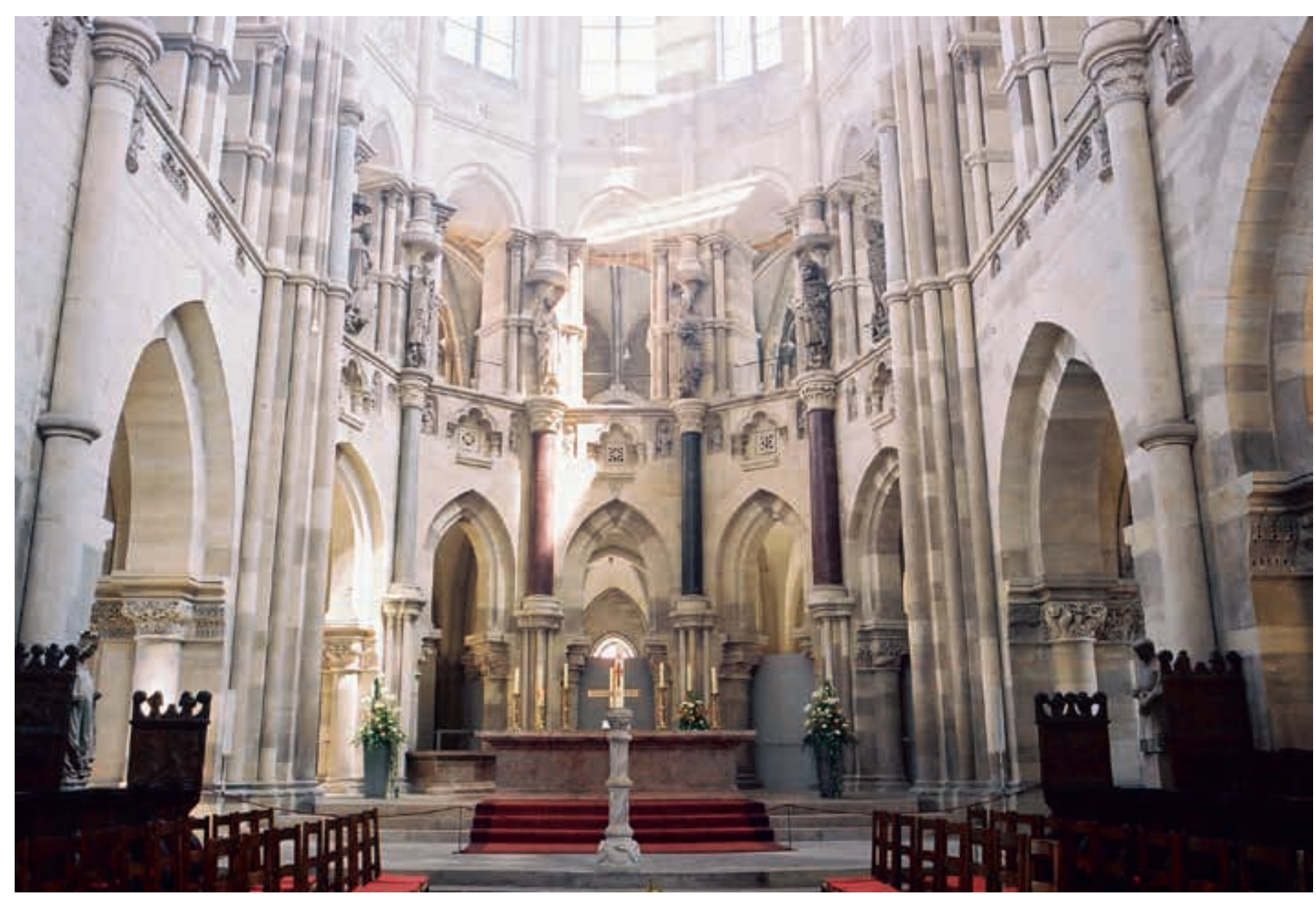

Een mooie omschrijving van authenticiteit in architectuur zou kunnen zijn dat een gebouwd object - of een onderdeel daarvan - ook werkelijk is wat het aangeeft of lijkt te zijn, een definitie verwant aan het existentialisme. In een eenvoudige definitie wordt in de filosofie bedoeld dat authenticiteit de mate is waarin iemand trouw blijft aan zichzelf, ondanks invloeden van buitenaf. Tegelijk maakt vrijwel elke omschrijving van authenticiteit duidelijk dat dit begrip beperkt bruikbaar is bij het onderzoeken van architectuur. In dit artikel probeer ik de bovengenoemde definitie toe te passen op de architectuur van de Oudheid, de late Oudheid en de Middeleeuwen. Daarnaast verken ik enkele andere invullingen van het begrip authenticiteit. 


\section{SPOLIA}

In de architectuur van de genoemde perioden doen dragende delen, zoals zuilen, in de regel datgene waarvoor ze bedoeld waren, namelijk het dragen of ondersteunen van een deel van het gebouw. Door hun toepassing maken ze de essentie van het architectuursysteem duidelijk en in die zin zijn ze authentiek. Voor het begrip authenticiteit is ook de vraag naar de toepassing en het materiaal van deze dragende delen interessant. De in de Oudheid en Middeleeuwen veelvuldig voorkomende zuilen kunnen immers veel ouder zijn dan het gebouw waarin ze zijn toegepast; dergelijke elementen werden niet zelden hergebruikt in een nieuwe context. Dit soort hergebruik van materiaal vanaf de late Oudheid tot diep in de Middeleeuwen, 'spolia' genoemd, roept andere vragen op die verband houden met authenticiteit. Het kon zijn dat ouder materiaal in een nieuwe context bouwkundig een andere functie kreeg dan het oorspronkelijk had. Dit zien we in de nieuwe bisschopskerk van Maagdenburg, die vanaf 1209 werd gebouwd ter vervanging van zijn door brand verwoeste voorganger. Veel van de Romeinse spolia-zuilen in deze kerk werden op een andere manier gebruikt. De meest in het oog springende zuilen van kostbare graniet- en porfiersoorten, het viertal in de apsis van de Dom, hebben geen constructieve functie. Ze lijken daarmee niet te voldoen aan het aan het begin van dit artikel geformuleerde uitgangspunt van authenticiteit (afb.1). Desalniettemin zijn ze juist om hun (authentieke) Romeinse oorsprong ooit vanuit Italië naar Maagdenburg gebracht en hebben ze ook daarom deze prominente positie gekregen. De bouwgeschiedenis van de nieuwe Dom bevat de nodige aanwijzingen dat nadrukkelijk is gezocht naar een in het oog springende plaats voor de bontgekleurde zuilen, die uiteindelijk in de apsis werd gevonden. ${ }^{1}$ Hier won de betekenis het van de oorspronkelijk functie van de zuilen.

In de meeste gevallen werd ouder materiaal echter opnieuw gebruikt in dezelfde rol als de oorspronkelijke - dus in lijn met de aan het begin genoemde definitie. Een bekend voorbeeld hiervan is het wijdverbreide hergebruik van zuilschachten in kerkgebouwen: de functie van de zuilen bleef dezelfde, namelijk het dragen van een architraaf of boog. Dit hergebruik van oude bouwmaterialen kan voor een hedendaagse onderzoeker de vraag naar authenticiteit in de zin van oorspronkelijkheid op scherp stellen. In die tijd was dit echter geen punt van overweging. Zo is er niet de geringste aanwijzing dat spolia in de periode van het vroege christendom doelbewust werden toegepast, noch dat onderscheid werd gemaakt tussen nieuwe en hergebruikte zuilschachten. De tientallen hergebruikte zuilen in de grote vroegchristelijke basilieken SintJan van Lateranen en Sint-Pieter in Rome zijn daar toegepast vanwege het materiaal. Vooral bij de Sint-Pieter was de rijkdom van de gebruikte marmer- en granietsoorten van doorslaggevende betekenis, niet de vraag of het materiaal nieuw was of eerder was toegepast. ${ }^{2}$ Deze observatie is van belang voor de beoordeling van het hergebruik van materiaal zoals zuilschachten, architraafbalken, kapitelen en basementen. De beschikbaarheid van dergelijk materiaal is een wezenlijk punt. In de vierde eeuw bijvoorbeeld werden bij de bouw van kerken in Rome zuilen gebruikt die afkomstig waren uit oudere bouwwerken, maar ook zuilen uit eerder aangelegde voorraden. De oorspronkelijke context waarin dergelijk materiaal had gefunctioneerd, was niet van belang; het gebouw hoefde niet te worden opgetrokken uit materialen die uit dezelfde periode stamden. Kennelijk waren andere overwegingen belangrijker bij de keuze voor materialen en de vorming van een idee over het ontwerp, zoals de rijkdom van het materiaal die zichtbaar was aan de bonte kleuren. Waar het om ging was dat de spolia in de nieuwe context dezelfde functie hadden als ze in een eerdere situatie hadden vervuld.

\section{HERKENBAAR HERGEBRUIK}

Interessant bij dit alles is het punt van herkenbaarheid. Want wie zou in staat zijn geweest het onderscheid vast te stellen tussen de hergebruikte en de nieuwe zuilschachten in de vierde-eeuwse basiliek van Sint-Pieter in Rome? Pas in de zestiende eeuw waren kunstenaar Rafaël en schrijver Baldassare Castiglione in staat om te herkennen dat onderdelen van de sculptuur aan de Boog van Constantijn (ca. 315) uit verschillende perioden stamden, zo blijkt uit hun beroemde 'Brief aan Leo x'; zij beoordeelden de kwaliteit van sculptuur die uit uiteenlopende perioden dateerde ook verschillend. ${ }^{3}$ Interessant is dat daarbij niet de eenheid van materiaal ter discussie stond, maar de kwaliteit van de bewerking van de sculptuur.

In Rome en daarbuiten zijn spolia om uiteenlopende redenen toegepast, ook na de vierde eeuw. In sommige fasen nam men daarbij herkenbare elementen voor lief en werd niet verborgen dat sommige onderdelen waren hergebruikt. In andere perioden werden herkenbare kenmerken juist bewust gezocht, waarbij de (vermeende) oorsprong ervan in het geding kon zijn. In de dertiende-eeuwse kerk van Santa Maria in Aracoeli werd een tweede-eeuws basement gebruikt samen met een marmeren blok met een zichtbare middeleeuwse inscriptie; twee voorbeelden van hergebruikt materiaal op elkaar geplaatst. ${ }^{4}$ Bij de kort na het midden van de elfde eeuw begonnen bisschopskerk in Pisa werd ouder materiaal op een heel andere manier toegepast. In dit belangrijke kerkgebouw is een elders niet voorkomende rijkdom aan Romeinse en islamitische spolia ingezet om de positie van zowel de instelling als de stad krachtig tot uitdrukking te brengen. Verwikkeld in de rivaliteit met andere havensteden verwerkte Pisa 
plaatsen. De geschiedenis van een instelling of individuele opdrachtgever diende bij voorkeur in de architectuur zichtbaar te worden gemaakt, zodat een hecht verband kon worden gecreëerd tussen de geschiedenis en de eigentijdse situatie. ${ }^{8}$

Authenticiteit speelde ook geen rol bij hergebruik van materiaal. De herkomst van materiaal was in de periode van het vroege christendom geen punt van overweging, want de rijkdom van het materiaal was doorslaggevend. Gedurende de Middeleeuwen kwamen er meer bewuste toepassingen van ouder materiaal voor vanwege hun betekenis, maar daarbij lijkt het begrip oorspronkelijkheid meer op zijn plaats dan authenticiteit.
NOTEN

1 L. Bosman, 'Bedeutung der Tradition. Über die Spolien im Chorbereich des Magdeburger Domes', in: W. Schenkluhn en A. Waschbüsch (red.), Der Magdeburger Dom im europäischen Kontext, Regensburg 2011, 187-195.

2 F. Marcorin, 'Classicismo e reimpiego nei colonnati dell'antica basilica di San Pietro in Vaticano', in: Jahrbuch für Antike und Christentum 58 (2015), 138-163, 154-157; L. Bosman, 'Spolia in the Fourth-century Basilica', in: R. McKitterick e.a. (red.), Old Saint Peter's, Rome, Cambridge 2013, 65-80; L. Bosman, 'Constantine's Spolia. A Set of Columns for San Giovanni in Laterano and the Arch of Constantine in Rome', in: L. Bosman, I.P. Haynes en P. Liverani (red.), The Basilica of Saint John Lateran to 1600 , Cambridge 2020, 171-181.

3 F.P. di Teodoro, Raffaello, Baldassar Castiglione e la lettera a Leone X con l'aggiunta di due saggi raffaelleschi, Bologna 2003, 82. Een goede Engelse vertaling van de tekst: V. Hart en P. Hicks (red.), Palladio's Rome, New Haven/Londen 2006, 183.

4 P. Pensabene, 'Architectural Spolia and Urban Transformation in Rome from the Fourth to the Thirteenth Century', in: S. Altekamp, C. MarcksJacobs en P. Seiler (red.), Perspektiven der Spolienforschung 2. Zentren und Konjunkturen der Spoliierung, Berlijn 2017, 222-225.
5 K.R. Mathews, Conflict, Commerce, and an Aesthetic of Appropriation in the Italian Maritime Cities, 100o-115o, Leiden/Boston 2018, 126-146.

6 A. Peroni, 'Spolia e architettura nel Duomo di Pisa', in: J. Poeschke (red.), Antike Spolien in der Architektur des Mittelalters und der Renaissance, München 1996, 205-223.

7 D. Hochkirchen, 'Antike Säulen im Alten Dom. Ein Rekonstruktionsvorschlag zu den Seitenschiffarkaden der vorgotischen Kölner Bischofskirche', Kölner Domblatt 76 (2011), 77-107.

8 W. Schenkluhn, 'Bemerkungen zum Begriff des Architekturzitats', Ars 41 (2008), 3-12.

PROF. DR. L. BOSMAN is hoogleraar architectuurgeschiedenis aan de Universiteit van Amsterdam. Hij houdt zich bezig met de architectuur van de late Oudheid, Middeleeuwen en Renaissance, waarbij de betekenissen van architectuur een kernpunt vormen. Ook werkt hij aan een onderzoek naar nationaalsocialisme en architectuurgeschiedenis in Nederland 1933-1945.

\section{AUTHENTICITY AND MATERIAL A CONSIDERATION OF THE CONCEPT BASED ON EXAMPLES FROM (LATE)ANTIQUITY AND THE MIDDLE AGES}

\section{LEX BOSMAN}

It is not immediately clear whether the concept of authenticity can be applied to the architecture of (Late) Antiquity and the Middle Ages. If you were to apply the existentialist definition of the concept, you could say that an architectural element is authentic when it is what it purports or seems to be: a column, for example, should support something. Authenticity can also be understood in the sense of 'initial' and 'original'. A brief survey of a few examples reveals the importance of originality and, in particular, of the function of the architectural element. Examples like the eleventh/twelfth-century episcopal church of Pisa demonstrate that alongside the original function of an element, in this case columns, there could be multiple layers of meaning. On the other hand there is the redeployment of ancient columns in the thirteenthcentury Magdeburg Cathedral, where they have no load-bearing function, having been placed in the apse solely because of what they signify. Ultimately one can wonder whether the concept of authenticity can be usefully applied to the architecture of the periods in question. 